OPEN ACCESS

Citation: Eduardo Haddad, Patricio Aroca, Pilar Jano, Ademir Rocha, Bruno Pimenta (2020) A Bad Year? Climate Variability and the Wine Industry in Chile. Wine Economics and Policy 9(2): 23-35. doi: 10.36253/web-7665

Copyright: (c) 2020 Eduardo Haddad, Patricio Aroca, Pilar Jano, Ademir Rocha, Bruno Pimenta. This is an open access, peer-reviewed article published by Firenze University Press (http:// www.fupress.com/wep) and distributed under the terms of the Creative Commons Attribution License, which permits unrestricted use, distribution, and reproduction in any medium, provided the original author and source are credited.

Data Availability Statement: All relevant data are within the paper and its Supporting Information files.

Competing Interests: The Author(s) declare(s) no conflict of interest.

\section{A Bad Year? Climate Variability and the Wine Industry in Chile}

\author{
Eduardo Haddad ${ }^{1, *}$, Patricio Aroca ${ }^{2}$, Pilar Jano ${ }^{3}$, Ademir Rocha 4 , \\ Bruno Pimenta ${ }^{5}$ \\ ${ }^{1}$ Department of Economics, University of São Paulo (USP), São Paulo, Brazil. Email: \\ ehaddad@usp.br \\ ${ }^{2}$ Business School, Adolfo Ibáñez University (UAI), Viña del Mar, Chile. Email: patricio. \\ aroca@uai.cl \\ ${ }^{3}$ Business School, Adolfo Ibáñez University (UAI), Viña del Mar, Chile. Email: pilar. \\ jano@uai.cl \\ ${ }^{4}$ Department of Economics, University of São Paulo (USP), São Paulo, Brazil. Email: \\ ademir.rocha@usp.br \\ ${ }^{5}$ Department of Economics, University of São Paulo (USP), São Paulo, Brazil. Email: \\ brunoproencapp@usp.br \\ ${ }^{\star}$ Corresponding author
}

\begin{abstract}
Short-term climate conditions may affect crop yields and vintage quality and, as a consequence, wine prices and vineyards' earnings. In this paper, we use a Computable General Equilibrium (CGE) model for Chile, which incorporates very detailed information about the value chain of the wine sector in the country. Using information for the 2015-2016 harvest, we calibrate climate variability shocks associated with a "bad year" for the wine industry in Chile, when premature rains occurred in important wine regions, reducing the area harvested and leading to wines with less concentrated flavors, particularly for reds. We model the climate shocks as a productivity change in the grape-producing sector (quantity effect). Moreover, we model quality effects as a shift in the foreign demand curve for Chilean wine. Given the specific economic environment in the model and the proposed simulation, it is possible to note the reduction of Chilean real GDP by about $0.067 \%$. By decomposing this result, we verify that the quality effect has a slightly greater weight compared to the quantity effect.
\end{abstract}

JEL C68, Q13, Q54.

Keywords: climate variability, viticulture, wine, computable general equilibrium, Chile.

\section{INTRODUCTION}

Viticulture is particularly sensitive to climatic conditions. Climate is a factor that influences both the suitability of a region to ripen a specific variety of grapes and the resulting wine style (Jones, 2006). Short-term climate conditions may affect crop yields and vintage quality. As a consequence, 
the latter conditions affect wine prices (Oczkowski, 2016) and vineyards' earnings (Ashenfelter and Storchmann, 2010), also compromising the reputation of a wine region. Climatic conditions and their effects on the quantity (yields) and quality of grapes produced will likely have important economic implications to the wine industry (Jones et al., 2005; Webb et al., 2008; Hannah et al., 2013; Mozell and Thach, 2014; van Leeuwen and Darriet, 2016; Ashenfelter and Storchmann, 2016).

While average climate conditions determine wine styles and varieties planted across the globe, different studies have shown that weather (short-term climatic conditions) define the characteristics of the vintages in the wine regions, with implications for wine prices and vineyard profitability (Jones and Storchmann, 2001; Schamel and Anderson, 2003; Haeger and Storchmann, 2006; Ramirez, 2008; Webb et al., 2008; Ashenfelter, 2010; Ashenfelter and Storchmann, 2010; Nunes and Loureiro, 2016; Oczkowski, 2016). Climate variability is one of the main environmental causes of losses to the agricultural sector, with lower crop yields or failure due mainly to drought, frost, hail, severe storms, and floods. Some of such driving climatic factors on the yield of wine grapes include temperature, solar radiation, and $\mathrm{CO}_{2}$ concentration (Bindi et al., 1996).

Weather conditions that directly affect the cultivated and harvested area of wine grapes also affect the quality of the associated wine vintages (Nemani et al., 2001; Jones, 2004; Ramirez, 2008; Ashenfelter, 2010; Oczkowski, 2016). From a wider perspective, climate is part of the notion of "terroir", with which viticulture and the production of fine wines have a very close association (Jones et al., 2005). This concept involves matching wine grape varieties to particular combinations of climate, landscape and soils, within specific cultural contexts, to produce unique wines of particular styles (Seguin, 1986). On the one hand, climate change will alter these terroirs and potentially affect the quality of wine grapes produced (de Cortazar and Seguin, 2004) and, on the other hand, wine production and quality are chiefly influenced by site-specific factors, husbandry decisions, and shortterm climate variability (Jones and Hellman, 2003).

The aforementioned empirical literature on the impact of climate on yield variability and quality of wine grape relies mainly on partial equilibrium reduced-form econometric estimations. There is a plethora of studies that successfully isolate the effects of climate events on a variety of outcomes related to the wine sector in different parts of the world. However, there are not many studies exploring the systemic economic impacts of climate shocks on the grape and the wine sectors. This wider view is essential in a context of an integrated approach of the production value chain of the wine sector. Backward and forward linkages affect, to different extents, local and external demand by the various economic agents. It is not different for the wine industry, in which sectoral linkages play an important role (Gillespie and Clarke, 2015).

In this paper, we will examine the wider impacts of the unfavorable weather conditions that prevailed in the 2015-2016 season in Chile, reducing the volume and the quality of the wine grapes. In what follows, we discuss in Section 2 the climatic conditions in Chile associated with higher quality vintages. As shown in Ashenfelter (2010) for Bordeaux wines, weather conditions are a good predictor of a "good year", explaining quality and prices of mature wines of a vintage. We then highlight in Section 3 some of the structural features of the Chilean wine-industry value chain embedded in our database. Section 4 describes our empirical strategy, and Section 5 discusses the main results. Concluding remarks follow.

\section{WHAT MAKES A "GOOD YEAR" IN CHILE?}

Geographically, Chile is composed of fifteen regions. Eighty nine percent of wine grape production is concentrated in the central zone of the country, from the $\mathrm{V}$ region of Valparaíso to the VII region of Maule (SAG, 2017). This area has a Mediterranean climate with welldefined seasons. This climate is characterized by a longdry season with an average annual temperature of 14-15 degrees Celsius and an average accumulated rainfall of $400 \mathrm{~mm}$ per year, ranging from 260 to $700 \mathrm{~mm}$. Temperatures and rainfall vary from the coast to the Andes mountains (west to east) and from north to south. Temperature decreases from north to south while rainfall increases (INE, 2016; Asociación Nacional de Ingenieros Agrónomos Enólogos de Chile, 2016).

A "good vintage year" in Chile, assuming it implies high productivity combined with high quality wine grapes, is similar to a good vintage year in places of comparable latitude. Wine grapes require hot, dry, rainless summers and cool winters. Berry development and ripening require a dry atmosphere, moderate temperatures (15-40 degrees Celsius) and plenty of sunshine (Patil et al., 1995). Among climate variables, air temperature is the most important factor affecting physiological behavior of the grape and chemical changes that occur during formation and maturity (Jackson 2000, and Carbonneau et al. 2007 cited by Montes et al. 2012).

The timing for the occurrence of high temperatures is also key as it can cause completely different effects in terms of grape quality and development. According to 
Jones et al. (2005), the temperature during the growing season can affect grape quality and viability in several ways. For example, a number of days with temperatures above $10^{\circ} \mathrm{C}$ can initiate vegetative growth starting the growing season (Mullins et al., 1992). Also, during flowering and grape development, too high temperatures can cause: premature veraison (color change and beginning of sugar accumulation), high grape mortality, enzyme inactivation, and problems with flavor ripening (Mullins et al., 1992). However, during ripening, a high diurnal temperature range leads to synthesis of grape tannins, sugars, and flavors (Gladstones, 1992).

For the case of Chile, there is not much scientific information published as to what good and bad vintage years mean. The closest study is the one by Montes et al. (2012), who classify the viticultural potential for high-quality wine production considering the spatial differences across Central Chile, an area representing around $85 \%$ of all viticultural area in the country. This area is characterized by a Mediterranean climate with maximum temperatures ranging between 25 and 35 degrees Celsius during the growing season (September to March), and a total annual precipitation varying from 300 to $900 \mathrm{~mm}$, concentrated in the cold season (June to August). Vineyards are typically irrigated and trained in vertical shoot-positioning system.

Montes et al. (2012) elaborate different climatic indices, which help describe the main features of Chilean climate based on monthly mean data of temperature, rainfall, and pan evaporation over 1990-2005 for 54 climatic stations. They estimate heat accumulation during the growing season, thermal regime during ripening, and the potential water balance at the end of the growth cycle. They find that the spatial differences in climatic potential in Chile are best described by heat accumulation and March thermal amplitude (the difference between maximum and minimum temperatures of March). While they determine a wide range of viticultural climatic groups in Chile, most of the weather stations (59\%) were classified as having temperate warm and warm climates according to a heat accumulation index. These climates are thermally suitable for ripening of the main cultivated varieties in Chile, such as Cabernet Sauvignon or Merlot. However, they are detrimental for earliest cultivars, such as Sauvignon Blanc and Chardonnay in zones with high heat accumulation, possibly affecting their aromatic potential. This is consistent with the findings of Mills-Novoa et al. (2016) who suggest that viticultural suitability in the Maipo valley (located in Central Chile) may be limited in the future for producing high-quality grapes from cooler climate varieties.
Montes et al. (2012) also find that grape ripening is associated with low minimum night-time temperatures mostly around 8.5 and 10 degrees Celsius (consistent feature across all areas studied ${ }^{1}$ ); that proximity to the ocean has a strong influence; and that north to south orientation of climatic groups seems more relevant than east to west orientation.

Finally, they find a negative hydric balance during the warm season. This means there were almost no rainfall events during the growing season and fruit-ripening period, which, on the one hand, can reduce the development of some diseases but, on the other hand, can make the growing season highly dependent on irrigation in Central Chile.

In Chile, the harvest period goes from February to May depending on variety and location. Rainfall late in these months is detrimental for productivity as it promotes the rise of fungus. In general, cloudy weather, high humidity, low temperatures and rainfall during flowering and berry development are prone to spread diseases (Patil et al., 1995).

For anecdotal information of good and bad vintage years matching climate characteristics with wine tasting score ratings, Wine Spectator regional Vintage Charts provide yearly information that allows vintage comparison (Wine Spectator, 2020). These charts provide aggregate (average) characteristics of each vintage year and, in general, do not consider specific regions or varieties.

\subsection{The 2015-2016 Season in Chile}

The National Association of Oenologists 2016 Vintage Report classified the 2015-2016 season in Chile as complex due to climatic factors that affected wine grape health, ripening delay, and a productivity decrease of $30 \%$ on average. El Niño phenomenon greatly influenced climatic conditions presenting abnormally low rainfall during the 2015 winter and spring, and very intense rainfall starting on mid-April of 2016, around the middle of the vintage period. This rainfall episode and subsequent rainfall later in April exceeded a normal year and had a detrimental effect over grape health and productivity in Chile's central zone. Furthermore, a colder 2015 spring delayed budding, contributing to a ripening delay. These lower temperatures affected grape sugar content making it difficult to reach the 24 degrees Brix needed to produce a wine with 13 percent of alcohol by volume (Asociación Nacional de Ingenieros Agrónomos Enólogos de Chile, 2016). The most affected varie-

\footnotetext{
${ }^{1}$ This spatial consistency is uncommon in other wine-grape producing areas in the world.
} 
ties were Carménère, Petit Syrah, Malbec, Cabernet Sauvignon, Cabernet Franc, and Merlot. However, for grapes harvested before mid-April (mainly white grapes and some red grapes), acidity and freshness were high, resulting in high quality grapes for varieties that benefit from these characteristics (Wines of Chile, 2016).

Consequently, due to the particular climatic conditions on the 2015-2016 season, many localities resulted with lower quality wine grapes affected by diseases and lower productivity, especially those areas with grapes harvested after mid-April (Asociación Nacional de Ingenieros Agrónomos Enólogos de Chile, 2016).

\section{GRAPE AND WINE SECTORS IN CHILE}

We use the 2014 input-output system published by the Chilean Central Bank as the basis to calibrate a computable general equilibrium (CGE) model. The model is very detailed in its sectoral disaggregation, identifying 111 different sectors and 179 goods and services. This database represents the structure of the Chilean economy in 2014, just before the climate variability shock we want to analyze.

The grape and the wine sectors are fully integrated in the model. In 2014, the grape-growing sector was responsible for $0.33 \%$ of national GDP and $1.04 \%$ of total exports. Table grape was its primary output $(71.0 \%$ of total sectoral output), but the sector also produced wine grape (28.6\%), and other products (0.4\%). Most of the table grape's output was exported to other countries (85.5\%), while the remaining part went to household consumption (11.8\%), and a smaller share to other users $(2.7 \%)$. Wine grapes were destined either to the wine production $(90.7 \%)$ or to piscos and liquors production (9.3\%).

From a cost perspective, intermediate inputs were responsible for $45.0 \%$ of total costs of grape production, with the remaining $55.0 \%$ allocated to payments to primary factors and production taxes. The sector paid $81.1 \%$ of total intermediate inputs costs to domestic suppliers, with the main items being support activities for agriculture $(26.6 \%$ of total materials cost - only produced domestically); diesel (16.5\% of total $-27.2 \%$ from domestic sources); and fertilizers and pesticides (15.6\% of total $-75.3 \%$ domestic). Value added generated by the grape sector was relatively labor-intensive, with 53.7\% of payments to primary factors accruing to labor, and $46.3 \%$ to capital. ${ }^{2}$

The wine sector contributed with $0.30 \%$ of Chilean GDP in 2014, and was responsible for $2.30 \%$ of national

\footnotetext{
${ }^{2}$ As a reference, overall labor share in the Chilean economy was $42.9 \%$ in the benchmark year.
}

exports. In addition to the production of wine $(98.5 \%$ of total output), there was a secondary production of piscos and liquors (1.5\%). The wine production was mainly exported (73.7\% of total output), with the remaining part almost fully destined to household consumption (23.9\%) and to supply hotels and restaurants (2.4\%); piscos and liquors were directed to domestic consumption by households $(80.8 \%)$ with smaller shares sold to hotels and restaurants (6.8\%) and abroad (6.6\%), and the remaining share to the pisco sector.

The cost structure of the wine industry was divided into payments to intermediate inputs $(69.0 \%)$ and to primary factors and production taxes $(31.0 \%)$. The main input, wine grapes $(21.2 \%$ of total intermediate input costs), was fully supplied by the domestic grape sector. Other relevant input costs included glass $(11.8 \%$ of total - 98.2\% from domestic sources); paperboard (10.6\% of total - only produced domestically); and different professional services: other business services (8.9\%), marketing services (5.6\%) and personnel supply, cleaning, security and other support services (4.7\%). Storage and deposit costs were also relevant (4.2\%), as well as the use of other wood products (3.3\% of total intermediate input costs $-80.5 \%$ from domestic sources) and imported other metal products $(0.6 \%)$. Value added in the wine sector was capital-intensive, with $59.9 \%$ of payments to primary factors accruing to capital, and $40.1 \%$ to labor.

\section{THE MODEL}

We use a CGE model, calibrated for the Chilean economy, in order to evaluate the wider economic impacts of climate variability on the wine industry in the country. Our model's structure represents a variant of the well-documented ORANI-G model. ${ }^{3}$ The Chilean version of the model identifies 111 sectors and 179 goods and services, one service used as margin (trade services), indirect, value added and production taxes, and five user groups (producers, investors, household, foreign sector and government).

The CGE model allows capturing economy-wide effects through an intricate plot of input-output relations. We calibrate the climate shocks defining two main channels to translate physical variables into economic inputs to the CGE models. Because we do not estimate econometrically the direct links between the climate scenario and the economic variables, we build narratives based on the expert literature to quantify the stylized exogenous scenarios to feed the CGE model.

\footnotetext{
${ }^{3}$ Dixon et al. (1982), and Horridge (2000).
} 
The first channel - quantity channel - is derived from a decrease in productivity of the grape sector. We use information for the 2015-2016 grape harvest, which is usually associated with a bad year for the wine industry in Chile, since premature rains occurred in important wine regions, reducing the area harvested, and leading to wines with less concentrated flavors, particularly for reds, as perceived by consumers (Wine Spectator). According to data from the USDA Foreign Agricultural Service, grape production reduced by $-10.59 \%$ in the period. The varieties Cabernet Sauvignon, Carménère and Petit Verdot in the Metropolitan Region of Santiago, O'Higgins and part of the Maule region were the most affected (see Figure 1). Weather conditions, characterized by heavy rains followed by high temperatures, was favorable for the development of Botrytis fungus that causes fruit rot. In addition, many fruits were still in the vines when heavy rains began, making the losses even more substantial (USDA, 2016). We model this channel of climate shocks as an exogenous productivity change (all input augmenting technical change) in the grapeproducing sector (quantity effect), decreasing overall sectoral productivity by $-10.59 \%$ so that, coeteris paribus, the model imposes an initial reduction in grape production similar to that observed. ${ }^{4}$

According to the model's analytical structure, the quantity channel can be decomposed into two different channels. First, a price change channel: as productivity declines, this represents, on one hand, increases in the prices of grapes (both table grapes and wine grapes), increasing production costs to the wine sector and raising the costs for domestic and foreign consumers, which lower both domestic and external demand. This creates room for decreasing firms' output - destined for both domestic and international markets - which requires less inputs and primary factors. Decreasing demand puts pressure on the factor markets for price decreases, with a concomitant expectation that the prices of domestic goods would decrease. Second, the reduction in overall productivity is also associated with an increase in the inputs and primary factors requirements per unit of output in the grape sector (technical change channel). This creates an upward pressure on input prices, wages and capital rentals, which are passed on in the form of higher prices.

The second channel - quality channel - is associated with an expert perception of a lower quality vintage

\footnotetext{
${ }^{4}$ The "all input augmenting technical change" variables are sectoral-specific technological change variables, normally exogenous (values fixed outside the model). Suppose output were fixed, a shock of $-10 \%$ to the component of such variable of the wine sector would mean that $10 \%$ more of all inputs were needed to produce the benchmark wine output. For technical details, please refer to Dixon et al. (1982), and Horridge (2000).
}

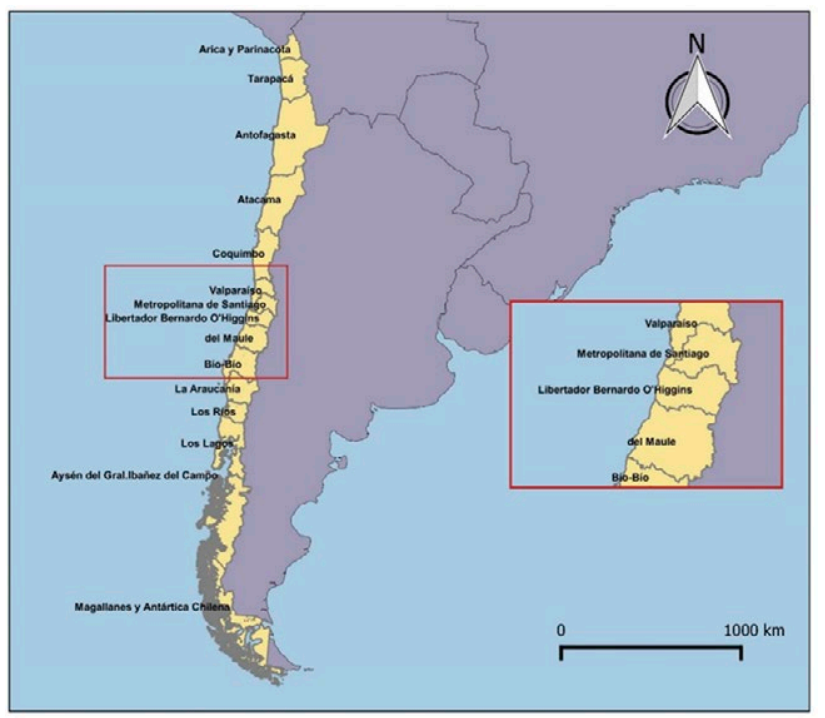

Figure 1. Regions Most Affected by Climate Variability.

of Chilean wines in 2016. The climatic adversity in 20152016 also brought about implications for the quality of the wines produced in Chile in 2016. Climate conditions in this "bad year" generated wines with slightly different characteristics from those more commonly found in Chilean wines (USDA, 2016). Table 1, drawn from the Wine Spectator magazine, shows the average vintage ratings for Chilean red wines for the period 2012 to 2016. It is possible to see that the rating for 2016 dropped five points in one year, passing from a score of 92, in 2015, to 87, in 2016.

Lower scores in vintage ratings may be associated with lower prices (premium). In a study by Schamel and

Table 1. Vintage Ratings - Chile: Reds (all regions).

\begin{tabular}{ll}
\hline Vintage Score & \multicolumn{1}{c}{ Description } \\
\hline $2016 \quad 87$ & $\begin{array}{l}\text { Untimely rains in key regions such as Colchagua, } \\
\text { Maipo and Casablanca cut yields and led to less } \\
\text { concentrated flavors, particularly for reds }\end{array}$ \\
& $\begin{array}{l}\text { A warm growing season and good harvest weather } \\
\text { delivered powerful Cabernet Sauvignons and crisp, } \\
\text { fruity Pinot Noirs; average quality for whites } \\
2015\end{array} \quad 89 \begin{array}{l}\text { Spring frost cut crop; good quality fruit harvested; } \\
\text { crisp reds, savory whites } \\
\text { Cool vintage, delivering fresh, well-structured wines } \\
\text { with good balance in terms of concentration and } \\
\text { flavor } \\
\text { Warm summer weather resulted in an early harvest, } \\
\text { with clean, disease-free fruit and yields 15 percent } \\
\text { above average; late-ripening Carmenère performed } \\
\text { well }\end{array}$ \\
2014 &
\end{tabular}

Source: Wine Spectator 


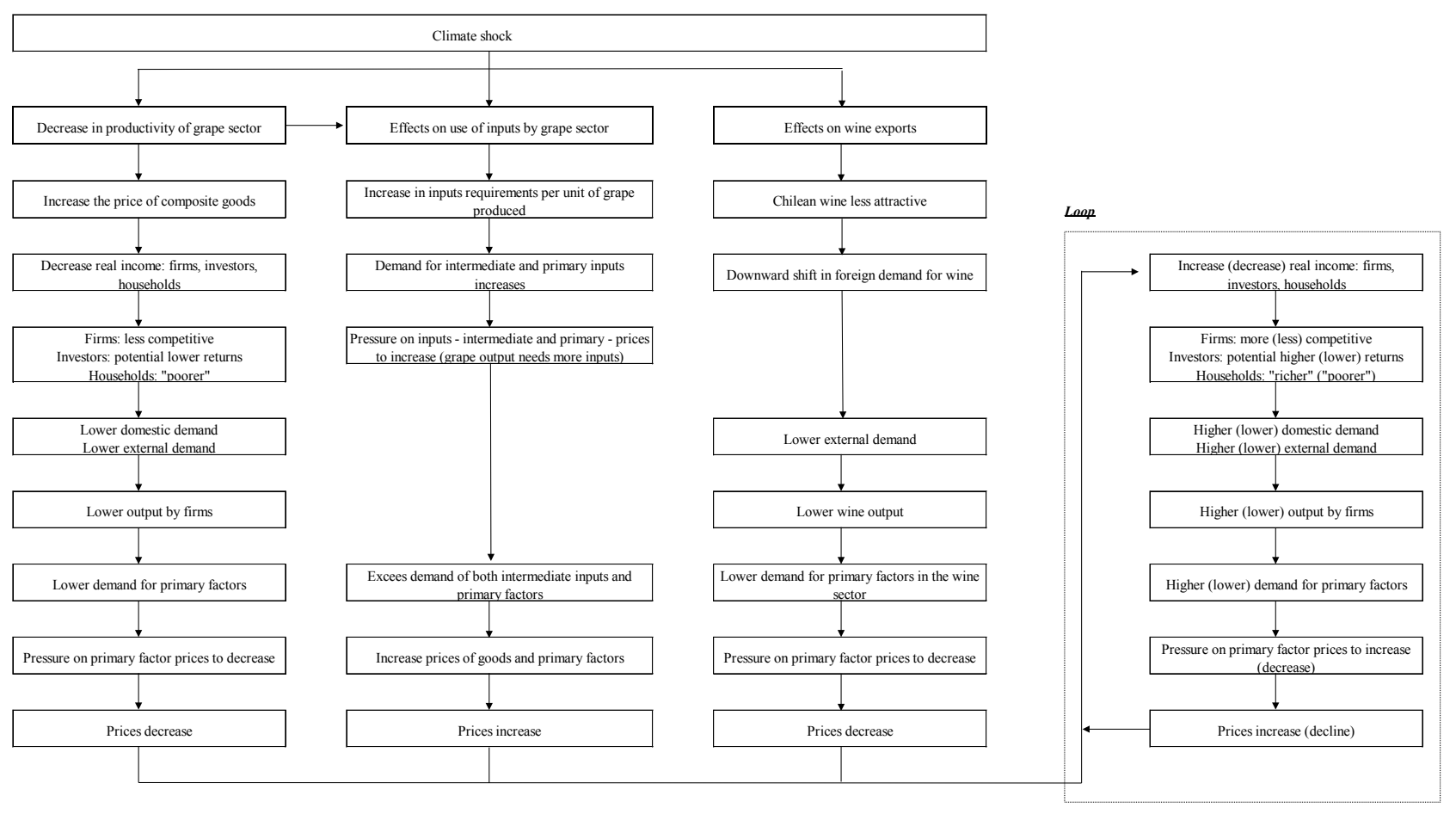

Price change channel

Technical change channel

Quality channel

Figure 2. Causal Relations Underlying the Simulation Results.

Anderson (2003), the authors estimated hedonic price functions for premium wine from Australia and New Zealand, differentiating implicit prices for sensory quality ratings over the vintages: the parameters for vintage rating were all significant and stable over time. The price premium was $3.1 \%$ on average and varied between $2.3 \%$ and $4.1 \%$ for one-point increase in the vintage rating for the 1992-2000 vintages.

Thus, given these two pieces of information, and considering the strong exposure of Chilean wines to international markets (almost $3 / 4$ of the output are exported), we model the quality channel as a downward parallel shift in the downward-sloping constant-elasticity export demand curve for Chilean wine in the model. In the specification of the model, foreign demands (exports) for domestic good $i$ depend on the percentage changes in a price, and two shift variables which allow for vertical and horizontal movements in the demand curves. The price variable, which influences export demands, is the purchaser's price in foreign countries, which includes the relevant taxes and margins. The parameter controls the sensitivity of export demand to price changes. Formally:

$$
\left(\operatorname{export}_{i}-f q_{i}^{(\text {export })}\right)=\eta_{i}\left(p_{i}^{(\text {export })}-p h i-f p_{i}^{(\text {export })}\right), \mathrm{i} \in \mathrm{G}
$$

Where $G=\{1, \ldots, g\}, g$ is the number of goods in the economy; export $_{i}$ is foreign demand for domestic good $i, p_{i}^{(\text {export })}$ is the purchasers' price in domestic currency of exported good $i$; phi is the nominal exchange rate; $f p_{i}{ }^{(\text {export })}$ and $f q_{i}{ }^{\text {(export) }}$ are, respectively, quantity and price shift variables in foreign demand curves for national exports.

We parameterize the size of the shock on $f p_{i}{ }^{\text {(export) }}$ by applying Schamel and Anderson's estimates to a fivepoint decrease in the vintage rating in 2016. Given the average price premium of $3.1 \%$ per point increase in the vintage-rating, we computed the compounded effect of a five-point difference, leading to an approximate $-14.16 \%$ price reduction associated with the same benchmark level of foreign demand for Chilean wine. ${ }^{5}$ Given the structure of the model, lower international demand for Chilean wines puts less pressure on prices through the decrease in export activity. ${ }^{6}$

Figure 2 summarizes the transmission mechanisms associated with first-order and second-order effects in the adjustment process underlying the model's aggregate results in the context of the major channels through which the shocks operate. Second-order prices changes

\footnotetext{
${ }^{5}$ Formula: $\left(100^{\star}\left(\left(1 /\left(1.031^{\wedge} 5\right)\right)-1\right)\right)$

${ }^{6}$ The relative strength of this channel is directly related to the magnitude of the short-run export demand elasticity (for Chilean wines), .
} 
go in both directions - decrease and increase. The net effect is determined by the relative strength of the countervailing forces.

\section{RESULTS}

To measure the wider impacts of the prevailing climatic conditions that affected grape and wine production in Chile in 2016, we run the model under a shortrun macro-adjustment closure. ${ }^{7}$ On the supply-side, we make the capital stock, technology, and the real wage exogenous. With the real wage given, the model can determine aggregate employment. With employment, technology and capital determined, the model can determine aggregate output (GDP). On the demand side, aggregate investment, and other demands (and inventories) are fixed. We allow (i) government consumption to move with tax revenue, and (ii) household consumption to move with factor income. With GDP determined from the supply side and domestic absorption (household consumption, investment, government consumption and inventories) defined as previously indicated, the trade balance must act as an endogenous 'swing' variable to satisfy the GDP identity. That is, if as a result of our shock GDP increases/decreases relative to domestic absorption, the trade balance must move toward surplus/ deficit.

Table 2 presents the simulation results for GDP and its components. It breaks down changes in real GDP into the contributions of the main expenditureside components, also decomposing the total impacts associated with the quantity and the quality channels. This enables us to verify how much of the change in real expenditure-side GDP is due, say, to a change in exports, associated with each channel. Table 2 also breaks down changes in real GDP from the income side, presenting the contributions to GDP due to primary factor usage, indirect taxes, and technical change. The combined effects of lower grape output and lower quality wine would lead to a reduction of Chilean real GDP by $-0.067 \%$, with similar contributions associated with the quantity channel $(-0.031 \%)$ and the quality channel $(-0.036 \%)$. Overall, a decrease in exports (negative impact on GDP of $-0.052 \%$ ), followed by a reduction in household consumption $(-0.028 \%)$ made the main contributions to the aggregate GDP result. In the case of exports, lower productivity in the grape-producing sector (quantity channel) increases the price of both exported table grapes and domestically consumed wine grapes,

\footnotetext{
${ }^{7}$ The closure is adapted from the standard short run closure described in Horridge (2000).
}

Table 2. Decomposition of the Impacts on Chilean GDP (\% contribution).

\begin{tabular}{|c|c|c|c|}
\hline & \multirow{2}{*}{ Total } & \multicolumn{2}{|c|}{ Subtotal } \\
\hline & & Quantity & Quality \\
\hline Real GDP from expenditure side & -0.067 & -0.031 & -0.036 \\
\hline Aggregate real investment expendiutre & 0.000 & 0.000 & 0.000 \\
\hline Real houselhold consumption & -0.028 & 0.027 & -0.055 \\
\hline Export volume & -0.052 & -0.035 & -0.017 \\
\hline Aggregate real government demands & -0.001 & 0.001 & -0.001 \\
\hline Import volume & 0.014 & -0.024 & 0.037 \\
\hline Real GDP from income side & -0.067 & -0.031 & -0.036 \\
\hline Use of capital & 0.000 & 0.000 & 0.000 \\
\hline Use of labor & -0.006 & 0.021 & -0.028 \\
\hline Indirect taxes & -0.004 & 0.004 & -0.009 \\
\hline Technical change & -0.057 & -0.057 & 0000 \\
\hline
\end{tabular}

in the latter case indirectly affecting prices of wine exports. As for the quality channel, the shift in export demand for Chilean wines directly impacts export volumes. Thus, exports results go in the same direction in both channels.

In the case of real household consumption, nonetheless, the results for its contributions to GDP, associated with the quantity and the quality channels, go in different directions. According to our model, with fixed capital stocks, the supply elasticity can be approximated by the expression that reflects its close connection with the elasticity of substitution between capital and labor, the shares of labor and capital in primary factor costs, and the share of primary factors in total costs. In other words, for given values of the substitution elasticity, supply is more elastic as either the labor/capital ratio is higher, or the share of materials in total cost is higher (Dixon et al., 1982). As seen in section 3, the grape sector is characterized as a labor-intensive sector. Within the quality channel, the technical change channel dominates primary factors market outcomes, generating higher labor absorption (positive impact on incomeside GDP of $0.021 \%$ ), and an increase in household consumption (positive impact on expenditure-side GDP of $0.027 \%$ ). This creates an upward pressure on input prices, wages and capital rentals, which are passed on in the form of higher prices, as can be seen at the bottom estimates of Table $3 .^{8}$

While the net effect of the quantity channel leads to real factor income increase, the outcome associated with the quality channel goes in the opposite direction, resulting in a decrease in household consumption. The initial decrease in economic activity associated with the foreign demand shift is accompanied by an overall reduction in employment and lower capital rentals, in a context of fixed capital stocks. Given that we set real

${ }^{8}$ Table 3 also presents results for factor payments (including prices and use), GDP components and price indices. 
Table 3. Impacts on Selected Macroeconomic Variables (in percentage change).

\begin{tabular}{|c|c|c|c|}
\hline & \multirow{2}{*}{ Total } & \multicolumn{2}{|c|}{ Subtotal } \\
\hline & & Ouantity & Ouality \\
\hline Aggregate primary factor payments & -0.143 & 0.233 & -0.376 \\
\hline Aggregate payments to capital & -0.164 & 0.224 & -0.388 \\
\hline Aggregate payments to labor & -0.115 & 0.246 & -0.361 \\
\hline Index of factor cost (excludes tech change) & -0.136 & 0.209 & -0.345 \\
\hline Average capital rental & -0.164 & 0.224 & -0.388 \\
\hline Average nominal wage & -0.099 & 0.190 & -0.288 \\
\hline Aggregate primary factor use (excludes tech change) & -0.007 & 0.024 & -0.031 \\
\hline Aggregate capital stock, rental weights & 0.000 & 0.000 & 0.000 \\
\hline Aggregate employment, wage bill weights & -0.017 & 0.056 & -0.073 \\
\hline Real GDP from expenditure side & -0.067 & -0.031 & -0.036 \\
\hline Aggregate real investment expendiutre & 0.000 & 0.000 & 0.000 \\
\hline Real houselhold consumption & -0.044 & 0.043 & -0.088 \\
\hline Export volume index & -0.159 & -0.107 & -0.052 \\
\hline Aggregate real government demands & -0.006 & 0.005 & -0.011 \\
\hline Import volume index, CIF weights & -0.043 & 0.075 & -0.119 \\
\hline Average real wage & 0.000 & 0.000 & 0.000 \\
\hline Real devaluation & 0.071 & -0.261 & 0.332 \\
\hline Consumer price index & -0.099 & 0.190 & -0.288 \\
\hline Exports price index, local currency & 0.045 & 0.269 & -0.223 \\
\hline Government price index & -0.099 & 0.179 & -0.277 \\
\hline
\end{tabular}

wages exogenously, imperfect substitutability between labor and capital helps explaining the stronger effect on capital costs.

One last comment on the macroeconomic results presented in Tables 2 and 3 relates to balance of trade effects. Real devaluation, defined as the ratio between the CIF import price index in local currency and the GDP deflator, shows how foreign prices move compared to local prices. In this formulation, the overall impact on this variable, $0.071 \%$, combines two different opposing forces. While the reduction in the productivity of the grape sector leads to overall higher domestic prices $(-0.261 \%)$, promoting import penetration, the lower demand for Chilean wine changes relative prices in favor of less expensive domestic goods (0.322\%), which, together with an overall lower activity level, help decreasing import demand. Accordingly, for exports, the vintage effect on real devaluation makes Chilean products more attractive to foreigners, partially offsetting the effect of the decrease in wine exports.

Table 4 highlights the importance of the impacts on the main products of the grape sector (wine and table grapes) and the wine sector (piscos and liquors, and wine) for the simulation results, revisiting some of the macroeconomic effects previously described. It captures the relevance of forward linkages in the wine industry value chain, revealing features of each product's sales structures, as described in section 3 . We focus on two main final users, namely households and exports. The reduction in the consumption of table grapes by households $(-4.932 \%)$ and foreigners $(-6.308 \%)$, its two main markets, is mainly associated with the rise in prices due to productivity changes. As a result, total output drops
Table 4. Impacts on Household Consumption, Exports and Output of Selected Products (in percentage change).

\begin{tabular}{|c|c|c|c|c|c|c|c|c|c|}
\hline & \multicolumn{3}{|c|}{ Household consumption } & \multicolumn{3}{|c|}{ Exports } & \multicolumn{3}{|c|}{ Output } \\
\hline & Total & Quantity & Quality & Total & Quantity & Quality & Total & Quantity & Quality \\
\hline Wine grapes & 0.000 & 0.000 & 0.000 & 0.000 & 0.000 & 0.000 & -3.194 & -0.751 & -2.443 \\
\hline Table grapes & -4.932 & -4.717 & -0.215 & -6.308 & -6.289 & -0.019 & -5.789 & -5.749 & -0.040 \\
\hline Piscos and liquors & -0.450 & -0.414 & -0.036 & -0.329 & -0.514 & 0.186 & -0.793 & -0.951 & 0.157 \\
\hline Wine & 0.129 & -1.017 & 1.145 & -4.788 & -0.644 & -4.143 & -3.951 & -0.822 & -3.130 \\
\hline Total in Chile & -0.044 & 0.043 & -0.088 & -0.159 & -0.107 & -0.052 & -0.048 & -0.012 & -0.035 \\
\hline
\end{tabular}

by $-5.789 \%$, a decrease mostly due to the quantity channel. Wine grapes, which supply exclusively to the wine sector, perceive an output decrease of $-3.194 \%$; roughly $1 / 4$ of this change due to the productivity effect in the grape sector and $3 / 4$ due to backward linkages associated with the vintage effect that affects wine exports.

The wine output, on its turn, decrease by $-3.951 \%$, with most of this outcome associated with the quality effect (-3.130\%). Interestingly, despite a sharp reduction in sales to foreign markets (-4.788\%), domestic sales to households increase $0.129 \%$. The higher domestic consumption (1.145\%), led by lower relative prices due to the shrinkage of sales to foreigners, offsets the negative local sales to final consumers when climate shocks harm yields of grape crops (-1.017\%), raising local wine prices as domestic wine grapes, the main input of the wine industry, become more expensive. Piscos and liquor output decreases to a lesser extent $(-0.793 \%)$. However, we see a shift of production of the wine sector from wine to piscos and liquors, as the former becomes less "attractive". This might be a path to follow as a potential adaptation measure given that there is an increase in exports due to quality (which in annulated by the quantity effect), which might be pursued to face a bad climate in a year. ${ }^{9}$ Therefore, the vineyard can substitute wine production by spirits production in order to face the fall in the wine demand by household and international consumer. At the microlevel, this might be a strategy for those producers of grape that can be used in pisco and liquor production, which are at the north part of the grape zone cultivation.

Finally, we have also calculated the impacts on sectoral output of the climate variability scenario that affected grape harvests in Chile. Figure 3 highlights those sectors that achieved the top and bottom performance. Sectors are ranked by the total effects. Backward and forward linkages play an important role in the picture that emerges.

\footnotetext{
${ }^{9}$ The specification of the sectoral composition of production is derived from the firm's maximization of revenue from all commodity outputs, subject to a constant elasticity of transformation (CET) production function. The model allows for secondary production, i.e. each sector can produce a mixture of all commodities. Given the CET specification, the output mix of each sector varies with the relative prices.
} 


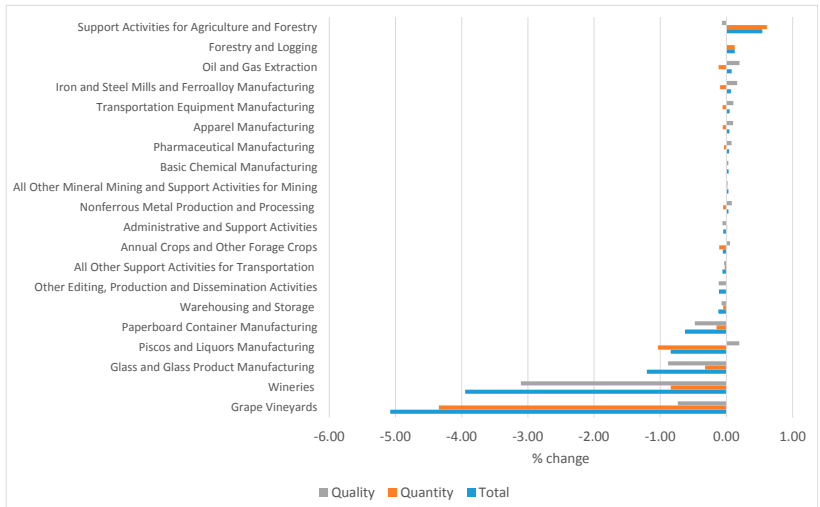

Figure 3. Impacts on Sectoral Activity (in percentage change).

According to Figure 3, in addition to the two sectors directly affected by the quantity and quality channels (grape vineyards and wineries), the sectors (indirectly) most affected by climate anomalies that hit grape yields are those related to the wine industry value chain.

To better understand the sectoral results of the model, a brief analysis of the structure of the economy can be done (Haddad, 2009). A close inspection on the benchmark data is necessary, conducted primarily on the relationships in the input-output database. Understanding of disaggregated results may be achieved through econometric regressions on key structural coefficients. How important is the existing economic structure in explaining the sectoral results associated with climate anomalies in Chile? Do backward and forward linkages matter? To answer these questions, following Dixon et al. (2007), we regress the model results (sectoral activity level) against selected structural coefficients of the model, suggested by the previous discussion. The OLS regressions are shown in Table 5 and aim only at revealing some of the influence of the benchmark structure on the results, considering a regression for the overall results, and two regressions for the subtotals (quantity and quality decompositions). The selected structural indicators explain more than 90 percent of the variation across sectors in the CGE model results. Given the nature of our experiment, we included sectoral dummies for the grape and wine sectors, in attempt to isolate the sector-specific shocks in each analysis. Sectors that present higher decreases in their output tend to have an overall higher share of their sales to the wine sector, suffering from the effects in the production value chain. Also, sectors that face stronger negative effects tend to concentrate their sales to Chilean households. Thus, the extent to which climate anomalies faced by the grape-producing sector affect sectoral economic activity is conditioned by the
Table 5. Structural Analysis of Sectoral Activity Results.

Dependent Variable: ACT_SECT

\begin{tabular}{lccc}
\hline \multirow{2}{*}{ Variables } & \multirow{2}{*}{ Total } & \multicolumn{2}{c}{ Subtotal } \\
\cline { 3 - 4 } WINE_SH & $-4.205^{* * *}$ & $-1.006^{* *}$ & $-3.199^{* * *}$ \\
& $(0.301)$ & $(0.432)$ & $(0.132)$ \\
HH_SH & $-0.089^{* * *}$ & & $-0.048^{* * *}$ \\
& $(0.032)$ & & $(0.018)$ \\
D_GRAPE & $-4.143^{* * *}$ & $-4.064^{* * *}$ & \\
& $(0.118)$ & $(0.174)$ & \\
D_WINE & $-3.945^{* * *}$ & & $-3.145^{* * *}$ \\
& $(0.098)$ & & $(0.054)$ \\
EXP_SH & & $-0.121^{* *}$ & $0.051^{* *}$ \\
& & $(0.058)$ & $(0.022)$ \\
MAT_SH & & -0.121 & \\
& & $(0.076)$ & \\
Constant & $0.023^{*}$ & 0.073 & 0.012 \\
& $(0.013)$ & $(0.045)$ & $(0.008)$ \\
Observations & 111 & 111 & 111 \\
R-squared & 0.977 & 0.899 & 0.975 \\
\hline
\end{tabular}

Standard errors in parentheses

${ }^{* *} \mathrm{p}<0.01,{ }^{* *} \mathrm{p}<0.05,{ }^{*} \mathrm{p}<0.1$

Note: ${ }^{\star}$ ACT_SECT $=$ percentage change in sectoral activity level; WINE $\mathrm{SH}=$ share of total sales to the wine sector; $\mathrm{HH}$ SH $=$ share of total sales to households; D_GRAPE = dummy for the grape sector; D_WINE = dummy for the wine sector; EXP_SH = share of total sales to exports; MAT_SH = share of materials in total costs. I

structural characteristics of the productive system and macroeconomic outcomes.

\subsection{Sensitivity Analysis}

In CGE modeling, one possible way to overcome the scarcity of estimates of key parameters is to simulate results based on different qualitative sets of values for the behavioral parameters and structural coefficients (Haddad, 2009). Through the judgment of the modeler, a range of alternative combinations reflecting differential structural hypotheses for the regional economies can be used to achieve a range of results for a policy simulation. This method, called qualitative or structural sensitivity analysis, provides a "confidence interval" to policy makers, and incorporates an extra component to the model's results, which contributes to increased robustness through the use of possible structural scenarios. As data deficiency has always been a big concern in CGE modeling, one that will not be overcome in the near future, this method tries to adjust the model for possible parameter misspecification. If the modeler knows enough about the func- 
Table 6. Sensitivity Analysis Results: Export Demand Elasticity for Wine.

\begin{tabular}{|c|c|c|c|c|c|c|c|c|c|}
\hline & \multicolumn{3}{|c|}{ Benchmark } & \multicolumn{3}{|c|}{$2 x$} & \multicolumn{3}{|c|}{$5 x$} \\
\hline & Total & Quantity & Quality & Total & Quantity & Quality & Total & Quantity & Quality \\
\hline \multicolumn{10}{|l|}{ Household consumption } \\
\hline Wine grapes & 0.000 & 0.000 & 0.000 & 0.000 & 0.000 & 0.000 & 0.000 & 0.000 & 0.000 \\
\hline Table grapes & -4.932 & -4.717 & -0.215 & -5.099 & -4.736 & -0.363 & -5.398 & -4.770 & -0.628 \\
\hline Piscos and liquors & $-\mathbf{0 . 4 5 0}$ & -0.414 & -0.036 & -0.472 & -0.415 & -0.057 & -0.503 & -0.416 & -0.088 \\
\hline Wine & 0.129 & -1.017 & 1.145 & 1.060 & -0.901 & 1.961 & 2.784 & -0.687 & 3.471 \\
\hline \multicolumn{10}{|l|}{ Exports } \\
\hline Wine grapes & 0.000 & 0.000 & 0.000 & 0.000 & 0.000 & 0.000 & 0.000 & 0.000 & 0.000 \\
\hline Table grapes & -6.308 & -6.289 & -0.019 & -6.330 & -6.294 & -0.035 & -6.374 & -6.304 & -0.070 \\
\hline Piscos and liquors & -0.329 & -0.514 & 0.186 & -0.175 & -0.491 & 0.316 & 0.104 & -0.448 & 0.551 \\
\hline Wine & -4.788 & -0.644 & -4.143 & -8.182 & -1.102 & -7.080 & -14.429 & -1.946 & -12.483 \\
\hline \multicolumn{10}{|l|}{ Output } \\
\hline Wine grapes & -3.194 & -0.751 & -2.443 & -5.197 & -1.023 & -4.174 & -8.881 & -1.524 & -7.357 \\
\hline Table grapes & -5.789 & -5.749 & -0.040 & -5.826 & -5.755 & -0.071 & $-\mathbf{5 . 8 9 7}$ & -5.768 & -0.129 \\
\hline Piscos and liquors & -0.793 & -0.951 & 0.157 & -0.656 & -0.927 & 0.271 & -0.397 & -0.883 & 0.486 \\
\hline Wine & -3.951 & -0.822 & -3.130 & -6.517 & -1.171 & -5.346 & -11.236 & -1.813 & -9.423 \\
\hline \multicolumn{10}{|l|}{ Macroeconomic aggregates } \\
\hline Real GDP from expenditure side & -0.067 & -0.031 & -0.036 & -0.096 & -0.035 & -0.061 & -0.147 & -0.042 & -0.104 \\
\hline Aggregate real investment expendiutre & 0.000 & 0.000 & 0.000 & 0.000 & 0.000 & 0.000 & 0.000 & 0.000 & 0.000 \\
\hline Real houselhold consumption & -0.044 & 0.043 & -0.088 & -0.114 & 0.033 & -0.147 & -0.236 & 0.016 & -0.251 \\
\hline Export volume index & -0.159 & -0.107 & -0.052 & -0.201 & -0.112 & -0.089 & -0.277 & -0.122 & -0.155 \\
\hline Aggregate real government demands & -0.006 & 0.005 & -0.011 & -0.015 & 0.003 & -0.018 & -0.029 & 0.001 & -0.030 \\
\hline Import volume index, CIF weights & $-\mathbf{0 . 0 4 3}$ & 0.075 & -0.119 & $-\mathbf{0 . 1 3 8}$ & 0.062 & -0.200 & -0.305 & 0.038 & -0.343 \\
\hline Aggregate employment, wage bill weights & $-\mathbf{0 . 0 1 7}$ & 0.056 & -0.073 & $-\mathbf{0 . 0 7 5}$ & 0.047 & -0.122 & -0.176 & 0.032 & -0.209 \\
\hline
\end{tabular}

tioning of the particular economy, the model achieves a greater degree of accuracy when such procedure is adopted.

Qualitative sensitivity analysis is carried out in this sub-section in order to grasp a better understanding on the role played by the export demand elasticity for wine. Such parameter determines the strength of the responsiveness of the Chilean wine industry to price changes. Given the lack of specific estimates for Chilean wine ${ }^{10}$, it was calibrated with the short-run value 0.33 , based on estimates for agro-industrial products. Given the uncertainty about its value, we run sensitivity analysis for this parameter, choosing alternative values up to twice and five times higher. Table 6 summarizes the sensitivity of results for macroeconomic aggregates and selected products. Overall, they point to a stronger dominance of the quality effect, as the value of the parameter goes up. They also point to the magnification of the main results, reinforcing their direction.

\footnotetext{
${ }^{10}$ Muhammad et al. (2013) report a price demand elasticity for Chinese wine imports from Chile equal to -1.104 .
}

\section{CONCLUDING REMARKS}

In this paper we have computed estimates of the economy-wide impacts of the special weather conditions that prevailed in Chile and affected grape harvests in the country, also affecting the quality of the wine produced. We have used a national CGE model calibrated for the Chilean economy. We evaluated two main transmission channels of the climate variability shocks to the economy, namely a quantity channel originated in the grape vineyards, and a quality channel accruing to the wineries. The general equilibrium approach adopted in this work allowed a broader understanding of potential responses of the wine industry in Chile to a specific climate scenario taking into account its whole value chain. It helped telling a story that takes into account the grape and wine sectors embedded in a national economic system.

The results revealed the relevance of backward and forward linkages to understand the systemic effects. Revisiting the main results of the paper, a quick backof-the-envelope calculation using the estimates of the impacts on sectoral economic activity and structural coefficients computing sectoral shares in GDP shows that for each 1.00 Chilean Peso (CLP) of reduction in the combined sectoral GDP of the grape and wine sectors, 
there is an additional 1.39 CLP reduction in other sectors' GDP. ${ }^{11}$

The results are not without limitations. In our simulation-based approach, results depend heavily on the analytical, functional and numerical structures of the model. The usual issue of model pre-selection (Blaug, 1992), with its advantages and disadvantages for the purpose of this exercise, applies here. Moreover, in spite of taking a general equilibrium approach to understand the economic effects in the Chilean economy, the narratives we built to quantify the exogenous scenarios to feed the CGE model preclude how weather conditions may have affected other crops. Thus, in our attempt to isolate the main mechanisms that link physical (climate) shocks to economic shocks, we have focused our attention on those directly associated with the key players of the wine industry. As usual, additional research is needed to help providing further evidence to evaluate these issues more completely.

As a final comment, we recognize there is an ongoing discussion about the definition of terroir and, even more, there is a discussion about the existence of the concept of terroir (Pszczólkowski, 2014, Vaudour, 2002). Broadly, there are two definitions of terroir: one that does not incorporate human intervention (management and perception), and another definition that besides soil, climate, and variety combination, considers vineyard management and perception (tasting). Besides the discussion about the definition of terroir, Bramley and Hamilton (2007) show that terroir is spatially variable at the within-vineyard scale using precision viticulture techniques.

Considering this last fact and the definition by Seguin (1986) presented in the introduction section of this article, in order to include terroir in the model we would need detailed information of variety-soil-climate combinations together with vineyard management at the local level. To the best of our knowledge, this information is very limited in Chile (and very far from what is known in the old world about their terroirs). Nonetheless, from a methodological perspective, it would be feasible to specify the model for specific wine regions - as information becomes available. For example, according to the discussion in Section 2, we can conclude that valleys that produce reds such as Maipo and Colchagua were affected negatively by the 2015-2016 season climatic conditions, however, valleys like Casablanca, specialized in white wines may have benefited. In spite of data con-

\footnotetext{
${ }^{11}$ We have compared the GDP effects $(-0.067 \%)$ to the combined contributions of the grape and the wine sectors to this outcome, by multiplying their respective shares in GDP $(0.33 \%$ and $0.30 \%)$ to the simulated impact on their activity levels $(-5.062 \%$ and $-3.800 \%$, respectively).
}

straints, future research efforts in modeling the Chilean economy in an integrated manner should move towards multirregional modeling frameworks.

\section{ACKNOWLEDGEMENTS.}

Financial support from CONICYT-FAPESP 2018/08337-8 "Agricultural and agro-industrial sustainability in Chile: modeling the impacts of climate change and natural disasters in an integrated framework" is acknowledged. This work was also supported by the Brazilian Research Network on Global Climate Change FINEP/Rede CLIMA [grant 01.13.0353-00] and the INCT for Climate Change II (INCT-MC) [grant 2014/50848-9]. Eduardo A. Haddad acknowledges financial support from CNPq (Grant 302861/2018-1).

\section{REFERENCES}

Ashenfelter, O. (2010). Predicting the quality and prices of Bordeaux wine. Journal of Wine Economics, 5(1), pp. 40-52.

Ashenfelter, O. and Storchmann, K. (2016). Climate change and wine: a review of the economic implications. Journal of Wine Economics, 11(1), pp. 105-138.

Ashenfelter, O. and Storchmann, K. (2010). Measuring the economic effect of global warming on viticulture using auction, retail, and wholesale prices. Review of Industrial Organization, 37(1), pp. 51-64.

Asociación Nacional de Ingenieros Agrónomos Enólogos de Chile (2016). Informe Vendimia 2016 en Chile. Revista Iberoamericana de Viticultura, Agroindustria y Ruralidad, 3(9), pp. 164-183.

Bindi, M. et al. (1996). Modelling the impact of future climate scenarios on yield and yield variability of grapevine. Climate research, 7(3), pp. 213-224.

Blaug, M. (1992). The methodology of economics: Or how economists explain, Cambridge University Press.

Bramley, R. G., \& Hamilton, R. P. (2007). Terroir and precision viticulture: are they compatible? Journal International des Sciences de la Vigne et du Vin, 41(1), 1.

Carbonneau, A., Deloire, A. and Jaillard, B. (2007) La vigne: physiologie, terroir, culture, Dunod: Paris.

De Cortazar, I. and Seguin, B. (2004). Climate warming: consequences for viticulture and the notion of "terroirs" in Europe. In VII International Symposium on Grapevine Physiology and Biotechnology 689. pp. 61-70.

Dixon, P.B. et al. (1982). ORANI: a multisectoral model of the Australian economy, Amsterdam: North-Holland 
Pub. Co.

Dixon, P.B. and Parmenter, B.R. (1996). Computable general equilibrium modelling for policy analysis and forecasting. Handbook of computational economics, v. 1, pp. 3-85.

Dixon, P.B., Rimmer, M.T. and Tsigas, M.E. (2007). Regionalising results from a detailed CGE model: macro, industry and state effects in the US of removing major tariffs and quotas. Papers in Regional Science, 86(1), pp. 31-55.

Gillespie, R. and Clarke, M. (2015). Economic contribution of the Australian wine sector. Australian Grape and Wine Authority. Gillespie Economics \& AgEconPlus Pty Ltd Report. Retrieved from http://www. wineaustralia.com

Gladstones, J.S. (1992). Viticulture and Environment, Winetitles: Adelaide.

Haddad, E. A. (2009). Interregional Computable General Equilibrium Models. In: M. Sonis and G. J. D. Hewings (eds.). Tool kits in regional science: theory, models and estimation, Berlin: Springer, p. 119-154.

Haeger, J. W. and Storchmann, K. (2006). Prices of American Pinot Noir wines: climate, craftsmanship, critics. Agricultural Economics, 35(1), pp. 67-78.

Horridge, M. (2000). ORANI-G: a general equilibrium model of the Australian economy. Melbourne: Centre of Policy Studies and Impact Project, Monash University. Available at: http://www.monash.edu.au/policy/elecpapr/op-93.htm.

INE - Instituto Nacional de Estadísticas (2016). Medio ambiente. Informe Anual 2016.

Jackson, R.S. (2000). Wine science: Principles, practice, perception, 2nd edn AcademicPress: San Diego, CA.

Jones, G. V. (2006). Climate and terroir: impacts of climate variability and change on wine. Fine Wine and Terroir: The Geoscience Perspective, (9), pp. 1-14.

Jones, G. V et al. (2005). Climate change and global wine quality. Climatic Change, 73(3), pp. 319-343.

Jones, G. V. (2004). Climate change in the western United States grape growing regions. In: VII International Symposium on Grapevine Physiology and Biotechnology 689. pp. 41-60.

Jones, G. V. and Hellman, E. (2003). Site assessment. Oregon Viticulture, 7.

Jones, G. V. and Storchmann, K. H. (2001). Wine market prices and investment under uncertainty: an econometric model for Bordeaux Crus Classés. Agricultural Economics, 26(2), pp. 115-133.

Mills-Novoa, M, Pszczólkowski, P., and Meza, F. (2016). The Impact of Climate Change on the Viticultural Suitability of Maipo Valley, Chile, The Professional Geographer, 68 (4): 561-573.
Montes, C., Perez-Quezada, J. F., Peña-Neira, A., \& Tonietto, J. (2012). Climatic potential for viticulture in Central Chile. Australian Journal of Grape and Wine Research, 18(1), 20-28.

Mozell, M.R. and Thach, L. (2014). The impact of climate change on the global wine industry: challenges and solutions. Wine Economics and Policy, 3(2), pp. 81-89.

Muhammad, A., Leister, A. M., McPhail, L., and Chen, W. (2013). The evolution of foreign wine demand in China. Australian Journal of Agricultural and Resource Economics, 58, pp. 392-408

Mullins, M. G., Bouquet, A., and Williams, L. E. (1992). Biology of the Grapevine. Cambridge University Press, Great Britain, 239 pp.

Nemani, R.R. et al. (2001). Asymmetric warming over coastal California and its impact on the premium wine industry. Climate research, 19(1), pp. 25-34.

Nunes, P. A. and Loureiro, M. L. (2016). Economic valuation of climate change induced vinery landscape impacts on tourism flows in Tuscany. Agricultural Economics, 47(4), pp. 365-374.

Oczkowski, E. (2016). Hedonic wine price functions with different prices. Australian Journal of Agricultural and Resource Economics, 60(2), pp. 196-211.

Patil, V. K., Chakrawar, V. R., Narwadkar, P.R, and Shinde, G.S. (1995). Grape. In: D. K. Salunkhe and S. S. Kadam (eds.), Handbook of Fruit Science and Technology: Production, Composition, Storage, and Processing. CRC Press, p. 23-54.

Pszczólkowski, P. (2014). “Terroir” y “Climats”: ¿realidad o quimera?, RIVAR, 1(1), pp. 13-19.

Ramirez, C.D. (2008). Wine quality, wine prices, and the weather: is Napa "different"? Journal of Wine Economics, 3(2), pp. 114-131.

SAG (2017). Catastro Vitícola Nacional. Servicio Agrícola y Ganadero, División de Protección Agrícola y Forestal, Subdepartamento de Viñas, Vinos y Bebidas Alcohólicas.

Schamel, G. and Anderson, K. (2003). Wine quality and varietal, regional and winery reputations: hedonic prices for Australia and New Zealand. Economic Record, 79(246), pp. 357-369.

Seguin, G. (1986). “Terroirs" and pedology of wine growing. Experientia, 42(8), pp. 861-873.

Troncoso, J.L. and Aguirre, M. (2006). Price determinants of Chilean wines in the US market: a hedonic approach. Spanish Journal of Agricultural Research, 4(2), pp. 124-129.

U. S. Department of Agriculture (2016). Climatic conditions lower Chilean fruit production volumes. Retrieved from https://gain.fas.usda.gov/ Recent $\% 20$ GAIN\%20Publications/Climatic\%20Conditions\%20 
Lower\%20Chilean\%20Fruit\%20Production\%20Volumes_Santiago_Chile_5-27-2016.pdf

Vaudour, E. (2002). The Quality of Grapes and Wine in Relation to Geography: Notions of Terroir at Various Scales, Journal of Wine Research, 13(2), pp. 117-141.

Webb, L.B., Whetton, P.H. and Barlow, E.W.R. (2008). Climate change and winegrape quality in Australia. Climate Research, 36(2), pp. 99-111.

Wines of Chile (2016). Vintage 2016 Report. Summary available at: http://www.winesofchile.org/es/news/092016/vendimia-2016-revisa-el-informe-elaboradopor-vinos-de-chile.

Wine Spectator (2020). Vintage Charts, Chile: Reds. Available at: https://www.winespectator.com/ vintagecharts/search/id/4 